\title{
Esej
}

\section{Tomasz Łubieński}

\section{Długi Jan}

\author{
Long Jan
}

1.

Niezależnie od doniosłości publicystyki i eseistyki Jana Strzeleckiego, przedmiotem uwagi powojennej elity umysłowej był zawsze on sam. Jako postać. Długi Jan - tak nazywał go Andrzej Ziemilski, partner wspinaczkowy, towarzysz wypraw narciarskich i taternickich, socjolog i pisarz. Ascetyczny uśmiech. Mocny uścisk dłoni. Tak mógłby wyglądać Chrystus, gdyby dożył siedemdziesięciu lat. Człowiek gór. Obdarzony intelektualnym i fizycznym wdziękiem, który wspominają wszyscy go znający.

W środowisku roztrząsano trudne polityczne i ideowe wybory, których dokonywał. I od których się uchylał, co zawsze jakiś wybór oznaczało. Według wewnętrznego przekonania, pozostawał z pewnością wierny etosowi inteligenckiego lewicowego Żoliborza z WSM-owskich kolonii, gdzie podczas niemieckiej okupacji osoby podpadające pod ustawy norymberskie nie czuły się, tak jak to bywało gdzie indziej, zagrożone sąsiedzkimi donosami. Czy potem, już za Polski Ludowej, w szkole TPD nr 1 imienia Bolesława Limanowskiego przy ulicy Felińskiego 15, nawet w latach stalinowskich przedwojenni nauczyciele próbowali dochować wierności korczakowskim zasadom wychowawczym wbrew brutalnej radzieckiej pedagogice Antoniego Makarenki. Toteż mój licealny kolega, który wiele lat spędził we Francji i w Emiratach pomyślnie inżynierując, tłumaczył znajomym, po co wraca: że nie tyle do PRL-u, ile na Żoliborz.

Magdalena Grochowska napisała biografię Strzeleckiego, według własnych słów, „na przekór drapieżnym czasom"1. Ale za późno. Bo w tzw. międzyczasie, to znaczy od śmierci tytułowego protagonisty, odeszło zbyt wielu ważnych dlań osób. Stąd w książce nadreprezentacja rozmówców nawet o pokolenie młodszych od Strzeleckiego, którzy - szczerze mówiąc - im głębiej pogrążają się w przeszłości, tym mniej mają o niej do powiedzenia. Zwłaszcza o dramatycznych latach bezpośrednio po wojnie. Po prostu nie było ich jeszcze w ogóle albo nie było prawie, jako niedorostków, na świecie. A wyobraźnia czy erudycja nie zdoła nigdy zastąpić doświadczeń, będących udziałem tamtego pokolenia. Takich jak wojna, zagłada, powstanie warszawskie, hitlerowskie czy stalinowskie obozy, zbrodnie władzy ludowej czy znajomość arkanów życia na poszczególnych etapach ludowej rzeczywistości.

Przekonywająca wydaje się wyrozumiałość autorki dla „utopii lewicowo-humanistycznej Strzeleckiego” jako taktyki. Ograniczonego przeciwstawiania się złu. Prób wytargowania od deterministycznych praw historii jak najwięcej. W świadomości sytuacji bez wyjścia, kiedy nadzieję wypada odłożyć na bliżej nieokreśloną przyszłość. W przełomowym roku 1948, opuszczony przez starszych, doświadczonych, zasłużonych towarzyszy, Strzelecki również kapituluje. Błyskotliwy przywódca młodych socjalistów, autor szlachetnego manifestu $O$

\footnotetext{
${ }^{1}$ M. Grochowska, Strzelecki. Śladem nadriei, Warszawa 2014.
} 
bumanistycznym socjalizmie, którego nie chcieli i nie mogli zrozumieć nadgorliwcy rewolucji, działający z ideowym poświęceniem pod osłoną bagnetów pierwszego na świecie mocarstwa robotniczo-chłopskiego. Więc wstępuje Jan Strzelecki w szeregi Polskiej Zjednoczonej Partii Robotniczej. Ale już 13 sierpnia 1950 roku, razem z Andrzejem Ziemilskim, powtarza skrajnie trudny środkowy filar północnej ściany Zadniego Mnicha - jakby nie miał na świecie nic ważniejszego do roboty. Może po tym zwycięstwie na szczycie przynajmniej uda mu się zapomnieć o klęsce, jaką był dla socjalizmu Kongres Zjednoczeniowy PZPR i PPS, odbywający się 15 grudnia 1948 roku.

\section{2.}

Mogło być gorzej. Bywało gorzej. I trudno zgodzić się z autorką, kiedy w słowie wstępnym pisze od siebie, że „wśród dramatycznych wątków historii Polski XX wieku, rozprawa z lewicą socjalistyczną należy do kluczowych"2. A co z innymi rozprawami? Trwały o wiele krócej. Nie miały raczej charakteru debat ideowych. Kończyły się przed sądem, często pod ścianą.

Trudno też zgodzić się z Grochowską kiedy podkreśla, że z okresu PRL-u zamierza wydobyć odcienie szarości - „wbrew dzisiejszym upodobaniom do krzywdzących kontrastów w obrazie tamtego świata i wbrew skłonnościom do potępień”’ Szarości istotnie nie brakowało. Jak również tak zwanych - enigmatycznie „błędów i wypaczeń”, które stanowiły przecież integralną część ustrojowej ideologii i pragmatyki. A jeśli tylko zachodziła taka potrzeba, stawały się zbrodnią. Wystarczyło kilka lat stalinizmu, żeby zatruć powojenną pamięć historyczna.

Naszą małą stabilizację, jej marazm, też trudno do końca ocenić. Niektórzy wspominają lata sześćdziesiąte z zachwyceniem. Jednocześnie nostalgia za życiem codziennym w PRL-u, oparta na ignorancji i niepamięci (sławna szynka ,jak za Gierka”), ma się doskonale. Polska Ludowa w kultowych dzisiaj komediach Stanisława Barei jest krajem egzotycznie śmiesznym, królestwem absurdów „jak z Mrożka”, oczywiście, jeśli nie pamięta się tam zbytnio o bolesnym konformizmie, zniewoleniu, poniżeniu, w budowaniu których aktywny udział brała przez wiele lat peerelowska elita. Dopóki nie oprzytomniała, w znacznym stopniu dzięki arogancji ludowej władzy. Zanim ta ostatnia nie uznała za stosowne przypomnieć, kto tu naprawdę rządzi. A wtedy niejeden rozczarowany, rozgoryczony, entuzjasta, piewca nowego lepszego świata, jak mówi poeta, „czuły bywał dla siebie, bo nie był już pewien swojego”. Rozpoczynała się w nim przemiana poglądów, wielka rewizja, która mogła daleko zaprowadzić.

Więc politycznej empatii, niejako na kredyt, nie skapi Grochowska nawet takim ideologom i koryfeuszom nauki jak prof. prof. Żółkiewski, Wiatr czy Schaff. Chociaż bilans ich dokonań nie wygląda korzystnie. Działali summa summarum na szkodę idei socjalizmu, zwłaszcza, jeśli rozumieć ją w duchu Jana Strzeleckiego. A więc skłonnościom do potępień trudno się dziwić. Sławili karykaturę socjalizmu. A to, że w pewnym momencie wyrzekli się kłamstwa, któremu służyli, oznaczało tylko, że nie będą kłamać dłużej. Ale przecież tym samym nie zadośćuczynili dostatecznie za winy, jakich się dopuścili.

Dlatego też, niezależnie od późniejszej przyjaźni z Długim Janem i zasług wszelakich, uczynienie profesora Leszka Kołakowskiego niemal równorzędnym bohaterem książki, której tytuł brzmi przecież jednoznacznie Strzelecki, jest jednak nieporozumieniem.

Zanim zbliżyli się do siebie, byli zupełnie innymi ludźmi. Przyszły profesor, światowa sława, hunwejbinem-jakobinem, pryszczatym filozofem. Zresztą Grochowska wylicza też grzechy, które popełnił wobec starych profesorów. Już nie do naprawienia. Co najwyżej mógł po latach, już jako międzynarodowy autorytet, ułatwiać zawodowe życie polecanym przez tamtych uczniom.

Poza tym, że byli obaj, Strzelecki - dojrzały socjalista - i młody komunista - Kołakowski - ludźmi lewicy, różnili się przez wiele lat pod każdym względem. Temperamentem, środowiskiem, pochodzeniem, biografią. I datą urodzenia. Strzelecki był starszy o lat osiem, co w tamtym powojennym, burzliwym czasie, stanowiło 
różnicę epokową. Kiedy przyszło skonfrontować się z rzeczywistością, Strzelecki był już człowiekiem wewnętrznie uformowanym. Miał za sobą konspirację i powstanie. Chodź ranny wyszedł z tych prób obronną ręka, to znaczy bez intelektualnego załamania, utraty wiary w wartości; co więcej, z nadzieją na lepsze jutro. Jego utopia pozostała ewolucyjna, etyczna, sceptyczna. Kołakowskiego tworzyła się agresywnie, radykalnie: tej nie łagodziły żadne piękne, śnieżne i skaliste góry. W tym czasie Kołakowski wierzył w nowy, nieunikniony lepszy świat i zbudowania którego pragnął, bez względu na koszty. A nawet uważał, że powinny być one drastycznie wysokie. A Strzelecki najchętniej, zwłaszcza po doświadczeniach strasznej wojny, chciałby ich w ogóle uniknąć. Słowem, obaj nie mieszczą się w jednej książce. Niewygodnie im, przeszkadzają sobie, bo każdy zasługuje na osobną biografię. I dopiero wtedy staje się jasne, że mogli się wreszcie spotkać.

\section{3.}

Jakub Karpiński w swoich znakomitych Portretach lat. Polska w latach 1944-1988 syntetycznie i symbolicznie streszcza dzieje PRL-u. Rok po roku. Na tle sytuacji międzynarodowej. Przedstawia polskie życie ustrojowe, gospodarcze, codzienne. Obok wybitnych osiagnięć w kulturze i sztuce rażące, zwłaszcza po Październiku, nadużycia i represje. Jak skazanie na śmierć wiceprezesa Spółdzielni Garbarskiej w Radomiu. W tymże roku 1960 ma miejsce wystawienie Kartoteki Stanisława Różewicza na scenie warszawskiego Teatru Dramatycznego oraz premiera Zezowatego sžcześcia Andrzeja Munka. W roku 1962 skazano na rok więzienia Annę Rudzińską, sekretarkę Klubu Krzywego Koła i Polskiego Towarzystwa Socjologicznego za paryskie konszachty z Jerzym Giedroyciem. Ale jednocześnie ukazały się, m.in., Barbaraynńca w ogrodzৃie Zbigniewa Herberta i Mit śródzৃiemnomorski Mieczysława Jastruna. Rok 1965: zbrodnia sądowa, czyli kara śmierci dla dyrektora zakładów mięsnych Stanisława Wawrzeckiego i cztery dożywocia. Jednocześnie wielkie wydarzenia artystyczne: filmowe - Salto Tadeusza Konwickiego i teatralne, Tango Sławomira Mrożka.

Ja najlepiej zapamiętałem, pominięty zresztą przez Karpińskiego (brak miejsca), fakt rozstrzelania za szpiegostwo na rzecz USA pewnego inżyniera, którego nazwiska nie zachowała historia. Wracałem właśnie z bratniej Rumunii, wysłany tam na dwutygodniową dziennikarską wymianę. I dojeżdżając do Przemyśla rozmyślałem z satysfakcją o jakże łagodnym, w porównaniu z surowym reżimem Geniusza Karpat - Nicolae Ceausescu, życiu w Polsce. Pod liberalnymi rządami towarzysza Wiesława. Aż do chwili, kiedy z dworcowego głośnika popłynęła informacja o egzekucji szpiega. Zapewne żoliborscy liberałowie nie słyszeli o skazanym. I nie znali osobiście zabitych w majestacie prawa przestępców gospodarczych. Ale podobnie jak w wypadku bliskiej im Anny Rudzińskiej nie zdobyli się na jakiś zorganizowany akt protestu, jakim mogło być choćby, najprościej, złożenie legitymacji partyjnej. Podobny skutek usunięcia z partii zapewniało również wystapienie w obronie atakowanego na partyjnym zebraniu.

Jan Strzelecki miał wiele lepszych do tego okazji. Korzystali z nich jego przyjaciele, zyskując wolność za umiarkowaną cenę: odmowę paszportu czy cenzuralną interwencję. Pierwszą z tych okazji były popaździernikowe rozczarowania. Likwidacja „Po prostu” i rozpędzenie demonstracji studenckiej na placu Narutowicza czy odmowa obiecanej rejestracji czasopismu „Europa”. Walka z Kościołem, środowiskiem literackim, List 34. Rok 1968, wydarzenia marcowe i sierpniowa interwencja w Czechosłowacji. Grudzień 1970 roku na Wybrzeżu. Proces taterników. Radom 1976. Z okazji każdego z tych wydarzeń można było oczekiwać, że kto jak kto, ale Jan Strzelecki wystapi z partii, ale do tego nie doszło.

Więc uporczywy fakt pozostawania socjalisty Strzeleckiego w partyjnych szeregach stał się dla wielu punktem odniesienia, komentarzem do sytuacji, jej oceną. Zapewne przed Październikiem apostazja była zbyt ryzykowna, właściwie niemożliwa, zarówno dla Strzeleckiego, jak i dla każdego członka partii. Niezależnie od fizycznej odwagi, którą Strzelecki dysponował, niebezpiecznej dla niego samego i zadań, jakie mu w czasie okupacji powierzano (nie miał podobno instynktu samozachowawczego). Ale potem prostu niemożliwa sprawa po stała się jeszcze trudniejsza. Skomplikowana. Uwikłana w lojalność, zaufanie, nadzieję, choćby były złudzeniami. Myślę, że w etykę conradowskich kapitanów. Może przemawiało do niego również biblijne „nie 
sądźcie, abyście nie byli sądzeni”. Może i słuszne, ale politycznie nieskuteczne. Urodzony moralista nie nadawał się Strzelecki, jak wielu, do polityki. Brakowało mu agresji, nienawiści, pewności własnych przekonań. Cierpiał za to na nadmiar wahań, wątpliwości, na brak decyzji. Cierpiał? A może taki właśnie, przynajmniej jeden, wyjątkowy, jest potrzebny? I może właśnie dlatego pamięta się go tak wyraźnie, a zapomina mocnych ludzi, którzy zawsze mają rację, choćby ta racja się zmieniała.

Ja wspominam Strzeleckiego sportowo, nie ideowo. Ze wspinaczkowych igraszek, które uprawialiśmy na tzw. kogutkach w reglowym masywie Łysanek, oprowadzani przez Michała Jagiełłę. Strzelecki utknął tam w wysokiej, kruchej ściance. I niepokojąco długi czas wahał się, czy wytrawersować w prawo, czy w lewo. Aż wreszcie kilkoma mocnymi - krępuję się powiedzieć - małpimi ruchami, znalazł się na bezpiecznej, wyżej położonej skalnej półce, oświetlonej popołudniowym słońcem.

I wyobrażam sobie, że czasem, niezależnie od wyznawanego przezeń światopoglądu, odwiedza to miejsce. 